\title{
Pollen morphology and ultrastructure of selected species of Magnoliaceae
}

By: Feng-Xia Xu ${ }^{\text {a }},{ }^{*}$, Bruce K. Kirchoff ${ }^{\text {b }}$

$\mathrm{Xu}$, Feng-Xia, and B. K. Kirchoff. 2008. Pollen morphology and ultrastructure of selected species of Magnoliaceae. Review of Palaeobotany and Palynology 150: 140-153

Made available courtesy of ELSEVIER:

http://www.elsevier.com/wps/find/journaldescription.cws_home/503359/description\#description

***Note: Figures may be missing from this format of the document

\begin{abstract}
:
The pollen morphology and ultrastructure of 20 species, representing eight genera of the Magnoliaceae are described based on observations with light, scanning and transmission electron microscopy. The family represents a homogeneous group from a pollen morphological point of view. The pollen grains are boat-shaped with a single elongate aperture on the distal face. The tectum is usually microperforate, rarely slightly or coarsely rugulose. Columellae are often irregular, but well-developed columellae do occur in some taxa. The endexine is distinct in 14 species, but difficult to discern in the genera Parakmeria, Kmeria and Tsoongiodendron. Within the aperture zone the exine elements are reduced to a thin foot layer. The intine has three layers with many vesicular-fibrillar components and tubular extensions in intine 1 . The symmetry of the pollen grains, shape, type of aperture and ultrastructure of the intine show a remarkable uniformity in the family. Nevertheless there is variety in pollen size, ornamentation and the ultrastructure of the exine. The pollen of Magnoliaceae is an example of an early trend of specialization, and supports the view that Magnoliaceae are not one of the earliest lines in the phylogeny of flowering plants.
\end{abstract}

\section{Article:}

\section{INTRODUCTION}

The Magnoliaceae are a well defined family that has long been important for the phylogenetic understanding of the angiosperms. The Magnoliaceae were long considered the most archaic flowering plants, but recent molecular evidence has changed this view, nesting the order Magnoliales among the eumagnoliids (APGII, 2003; Sauquet et al., 2003).

The Magnoliaceae consist of about 230 species of trees and shrubs, characterized by distinct tepals, an androecium of numerous stamens and a gynoecium with many free carpels, spirally arranged on an elongated axis. All species have bisexual flowers except those in the genus Kmeria, and some species of Parakmeria, both of which have unisexual flowers. More than $80 \%$ of the species are distributed in subtropical and tropical regions of eastern Asia, with the remainder occurring in the Americas. The family is an outstanding example of intercontinental disjunction (Azuma et al., 2001).

\footnotetext{
${ }^{*}$ a South China Botanical Garden, Chinese Academy of Sciences, Leyiju Guangzhou 510650, China

${ }^{b}$ Department of Biology, P. O. Box 26170, University of North Carolina at Greensboro, Greensboro, NC 274026170, USA
} 
Dandy (1927) proposed the first comprehensive taxonomic treatment of the Magnoliaceae, which recognized ten genera separated into two tribes: Liriodendreae, with the sole genus Liriodendron, and Magnolieae, including Magnolia, Manglietia, Michelia, and six smaller genera. Two additional new, small genera were later accepted into his system (Dandy, 1964). Subsequent authors have proposed several different infrafamilial taxonomic schemes, but all divide the family into two subfamilies, one of which (Liriodendroideae) includes the sole genus Liriodendron, and the other (Magnolioideae) includes a variable number of genera.

Law's (1984) Magnolioideae includes two tribes: Magnolieae with terminal flowers, and Michelieae with axillary flowers. Nooteboom discarded all tribes and subtribes and reduced the genera of Magnolioideae first to six, later to two, and finally to one (Nooteboom, 1985, 2000; Cheng and Nooteboom, 1993; Figlar and Nooteboom, 2004). A recent phylogenetic tree based on $n d h F$ strongly suggests a taxonomic realignment considerably different from the traditional taxonomic treatment of the family (Kim et al., 2001). Kim et al. (2001) still support the separation of the Magnoliaceae into two subfamilies, but only recognize six genera in subfamily Magnolioideae.

There have been several studies of pollen morphology of the Magnoliaceae, illustrated with light and electron micrographs; however, studies employing scanning electron microscopy (SEM) have been few. General descriptions of pollen morphology were provided by Erdtman $(1952,1969)$, and some details of pollen structure were described based on light microscopy by Canright (1953), Agababian (1972), Walker (1976a,b) and Long (1982). Pollen wall development of three genera was investigated by Gabarayeva (1986, 1987b, 1991a, 1996). The pollen of Liriodenddron chinese was studied by Wei and Wu (1993) and the pollen morphology of nine species from five genera was reported in the monograph The World Pollen and Spore Flora (Praglowski, 1974). Unfortunately, most of these results were obtained from herbarium specimens. As a result of acetolysis, pollen shape varied considerably. Only nine species of Magnolia (Praglowski,1974), and one of Liriodendron (Wei and Wu, 1993), have been examined from fresh material, but even in these studies the grains were fixed and acetolyzed before SEM, which caused distortion of pollen shape.

Here, micromorphological features of the pollen grains of eight genera of Magnoliaceae are examined in detail based on fresh pollen. Our aim is to contribute to a clearer understanding of the pollen features of this family, and to acquire further evidence that can be used to assess the phylogenetic significance of pollen micromorphological features.

\section{MATERIALS AND METHODS}

Fresh pollen grains were collected from mature stamens before anthesis. Most specimens came from plants growing in the living Magnolia collections of the South China Botanical Garden, Chinese Academy of Sciences. Only pollen from Parakmeria yunnanensis came from a wild source. Voucher specimens are deposited in the herbarium of South China Institute of Botany (IBSC), and are listed in Table 1. At least 20 grains were observed for each species, with light, scanning and transmission electron microscopy. For light microscopy (LM), the fresh grains were acetolyzed and mounted in glycerine jelly (Erdtman, 1960). Pollen destined for SEM was placed directly on brass stubs without treatment, coated with gold using a JFC-110 sputter coater and observed with a JEM-T300 SEM. Only one species, Parakmeria yunnanensis, which was 
collected from Yunnan province, was fixed in FAA. For transmission electron microscopy (TEM), pollen grains were prefixed with 10/6 glutaraldehyde for $24 \mathrm{~h}$, and post-fixed with 10/6 osmium tetroxide $\left(\mathrm{OsO}_{4}\right)$. The pollen was dehydrated in an acetone series (30-1000/6), embedded in epoxy resin, sectioned on a Leica Ultra S-2, and stained with uranyl acetate (10/6) for 15 min followed by lead citrate (60/6) for $3 \mathrm{~min}$. The sections were examined with a JEM-100CXII transmission electron microscope.

The lengths of the longest axis (LA) and the shortest equatorial axis (SEA) were measured from 20 pollen grains per species using LM slides of pollen mounted in glycerin. Measurements of perforations and the thickness of the pollen wall were made on SEM and TEM images, based on 20 micrographs. Details for each species are given in Tables 1 and 2, where the genera are listed

Table 1

Species observed

\begin{tabular}{|c|c|c|c|c|}
\hline Species & Voucher (IBSC) & Omament. & Chromo. n. & Figures \\
\hline Manglietia fordiana Oliver & F. X. Xu 03042 & microperf. & $2 n=38$ & $9,30,55$ \\
\hline M. megaphylla $\mathrm{Hu}$ and Cheng & F. X. Xu 03032 & microperf. & $2 n=38$ & $11,31,56$ \\
\hline M. moto Dandy & F. X. Xu 01043 & microperf. & $2 n=38$ & $10,32,58$ \\
\hline M. rufibarbata Dandy & F. X. Xu 03035 & microperf. & $2 n=38$ & $13,34,57$ \\
\hline Magnolia delavayi Franchet & Y. Z. Liu 03098 & microperf. & $2 n=38$ & $16,35,60$ \\
\hline M. denudata Desrousseaux & F. X. Xu 02021 & microperf. & $4 n=76$ & $22,39,63$ \\
\hline M. paenetalauma Dandy & F. X. Xu 03031 & microperf. & $2 n=38$ & $14,37,61$ \\
\hline $\begin{array}{l}\text { Parakmeria lotungensis (Chun and } \\
\text { C.H. Tsoong) Yuh Wu Law }\end{array}$ & Y. Z. Liu 01045 & microperf. & $6 n=114$ & $\begin{array}{l}\text { bisex. } 18,41,67 \\
\text { male } 1,15,17,40 \text {, } \\
52,65,68\end{array}$ \\
\hline P. yunnanensis $\mathrm{Hu}$ & Y. Z. Liu 02059 & microperf. & $6 n=114$ & $\begin{array}{l}\text { bisex. } 23 \\
\text { male } 24,42,64\end{array}$ \\
\hline M. foveolata Merrill ex Dandy & F. X. Xu 93005 & rugulose & $2 n=38$ & $6,27,47,71$ \\
\hline M. skinneriana Dunn & F. X. Xu 93003 & rugulose & $2 n=38$ & $5,48,72$ \\
\hline Paramichelia baillonii (Pierre) $\mathrm{Hu}$ & F. X. Xu 94022 & microperf. & $2 n=38$ & $7,29,49,51,75$ \\
\hline Tsoongiodendron odorum Chun & F. X. Xu 94061 & microperf. & $2 n=38$ & $8,50,76$ \\
\hline
\end{tabular}

The chromosome numbers are from Li et al. (1998a,b), and Meng et al. (2006).

Abbreviations: Ornament. $=$ Ornamentation; Chromo. n. $=$ Chromosome numbers;

bisex.=bisexual, microperf. $=$ microperforate. 
Table 2

Pollen characters

\begin{tabular}{|c|c|c|c|c|c|c|c|c|c|c|c|c|c|}
\hline Species & LA & SEA & T. ex. & Tect. & Colum. & F. L. & T. int. & Int. 1 & Int. 2 & Int. 3 & End. & $\phi$ & P. T. \\
\hline Manglietia fordiana & $48-(56.5)-70$ & $20-(38.4)-40$ & 0.69 & 0.24 & 0.27 & 0.16 & 2.16 & 0.75 & 1.09 & 0.28 & + & 0.12 & 1 \\
\hline M. megaphylla & $78-(83.7)-90$ & $56-(64.9)-75$ & 0.31 & 0.19 & 0.06 & 0.09 & 3.08 & 1.28 & 1.30 & 0.46 & + & 0.17 & 1 \\
\hline M. moto & $63-(68.9)-74$ & $50-(60.0)-65$ & 1.24 & 0.42 & 0.61 & 0.23 & 3.88 & 1.24 & 1.63 & 0.99 & + & 0.15 & 1 \\
\hline M. pachyphylla & $58-(65.0)-71$ & 44-(49.3)-57 & 0.68 & 0.32 & 0.21 & 0.16 & 2.95 & 1.31 & 1.24 & 0.36 & + & 0.12 & 1 \\
\hline M. rufibarbata & $60-(69.5)-75$ & $50-(54.7)-60$ & 0.46 & 0.20 & 0.09 & 0.16 & 2.60 & 0.94 & 0.68 & 0.99 & + & 0.16 & 1 \\
\hline Magnolia delavayi & $80-(91.1)-106$ & $58-(68.9)-80$ & 0.57 & 0.19 & 0.23 & 0.18 & 2.01 & 0.61 & 0.99 & 0.43 & + & 0.18 & 1 \\
\hline M. denudata & $50-(56.1)-61$ & $38-(40.7)-45$ & 0.46 & 0.17 & 0.27 & 0.04 & 1.42 & 0.57 & 0.69 & 0.17 & + & 0.09 & 1 \\
\hline M. grandiflora & $75-(81.1)-88$ & $54-(57.5)-61$ & 1.12 & 0.69 & 0.24 & 0.22 & 1.71 & 0.61 & 0.75 & 0.31 & + & 0.31 & 3 \\
\hline$M$. henryi & $65-(74.4)-80$ & $50-(57.4)-65$ & 0.70 & 0.17 & 0.39 & 0.12 & 2.20 & 0.85 & 1.07 & 0.23 & + & 0.11 & 1 \\
\hline M. paenetalauma & $40-(48.7)-62$ & $20-(30.1)-41$ & 0.58 & 0.25 & 0.17 & 0.14 & 1.69 & 0.85 & 0.68 & 0.19 & + & 0.17 & 1 \\
\hline \multirow[t]{2}{*}{ Parakmeria lotungensis } & bisex. $70-(84.7)-95$ & $60-(71.9)-85$ & 1.14 & 0.30 & 0.69 & 0.13 & 3.51 & 1.39 & 1.29 & 0.79 & - & 0.10 & 1 \\
\hline & male $69-(83.6)-90$ & $58-(71.5)-86$ & 1.07 & 0.28 & 0.67 & 0.13 & 3.38 & 1.19 & 1.10 & 1.14 & - & 0.10 & \\
\hline \multirow[t]{2}{*}{ P. yunnanensis } & bisex. $35-(48.2)-60$ & $25-(34.8)-47$ & - & - & - & - & - & - & - & - & - & - & 1 \\
\hline & male $66-(79.4)-86$ & $52-(60.1)-64$ & 1.13 & 0.31 & 0.68 & 0.15 & 3.80 & 1.65 & 1.31 & 0.81 & + & 0.12 & \\
\hline Kmeria septentrionalis & $34-(37.9)-44$ & $25-(31.4)-34$ & 1.10 & 0.31 & 0.66 & 0.12 & 3.1 & 1.31 & 1.18 & 0.57 & - & 0.14 & 5 \\
\hline Alcimandra cathcartii & $31-(34.8)-39$ & $25-(27.7)-30$ & 0.48 & 0.21 & 0.16 & 0.09 & 0.82 & 0.15 & 0.39 & 0.25 & + & 0.10 & 2 \\
\hline Michelia balansae & $58-(64.3)-72$ & $31-(40.3)-59$ & 0.49 & 0.14 & 0.27 & 0.09 & 2.95 & 1.07 & 1.41 & 0.51 & - & 0.12 & 1 \\
\hline M. champaca & $36-(51.2)-55$ & $24-(34.4)-36$ & 0.57 & 0.20 & 0.26 & 0.10 & 1.46 & 0.44 & 0.61 & 0.39 & - & 0.26 & 1 \\
\hline M. foveolata & $43-(50.1)-68$ & $28-(32.6)-44$ & 0.49 & 0.24 & 0.13 & 0.10 & 1.23 & 0.48 & 0.34 & 0.41 & + & 0.12 & 3 \\
\hline M. skinneriana & $36-(46.9)-53$ & $26-(29.1)-36$ & 0.55 & 0.36 & 0.15 & 0.06 & 0.94 & 0.19 & 0.45 & 0.33 & + & 0.28 & 3 \\
\hline Paramichelia baillonii & $17-(23.2)-31$ & $14-(17.0)-19$ & 0.60 & 0.20 & 0.34 & 0.07 & 0.93 & 0.31 & 0.27 & 0.32 & - & 0.35 & 2 \\
\hline Tsoongiodendron odorum & $38-(40.3)-44$ & $26-(28.1)-30$ & 0.72 & 0.35 & 0.30 & 0.09 & 1.80 & 0.68 & 0.59 & 0.55 & - & 0.31 & 2 \\
\hline
\end{tabular}

All measurements are in $\mu \mathrm{m}$. Means are given in parentheses with flanking lower and upper ranges.

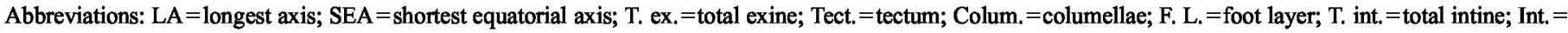
intine; End.=endexine; $\phi=$ diameter of the tectum perforation; $P$. T. = pollen type; bisex. =bisexual; $+=$ present; $-=$ difficult to discern; $-=$ not investigated.

according to Law's (1984) system, and then alphabetically by species. Descriptive palynological terms follow Punt et al. (2007). Pollen type is classified according to Praglowski (1974). Type 1: Pollen grains tectate, tectum surface smooth, longest axis $45 \mu \mathrm{m}$ or larger. Type 2: Pollen grains tectate, tectum surface smooth, longest axis $<45 \mu \mathrm{m}$. Type 3: Pollen grains tectate, tectum sculpturing slightly rugulose, longest axis $45 \mu \mathrm{m}$ or larger. Type 5 : Pollen grains tectate, tectum sculpturing coarsely rugulose.

\subsection{Observations}

\subsubsection{Pollen shape and sexine ornamentation}

The pollen occurs in monads of bilaterally symmetrical, heteropolar, monocolpate grains, with the colpus oriented parallel to the long equatorial axis. The aperture is simple, occurs on the distal face of the pollen grain, is usually long and narrow, and extends to the ends of the grain (Plates I, 1-18; II, 19-29). The pollen grains are boat-shaped with rounded or occasionally somewhat pointed ends in polar view. They are usually biconvex in lateral view (Plates I, 14; II, 20, 27). The longest axis of the grains ranges from $17-106 \mu \mathrm{m}$, with a mean from $23-91 \mu \mathrm{m}$ (Table 2).

The sexine is usually smooth, with microperforate ornamentation, rarely slightly rugulose or with coarse ornamentation. The perforations are randomly distributed, not in groups and without obvious differences from the distal to the proximal face (Plates II, 30-32; III, 33-50).

\subsubsection{Ultrastructure of the pollen wall}


The pollen wall is composed of both an intine and a tectate-columellate exine. The exine consists of three distinct layers: tectum, columellae, and nexine (Plate IV, 53). It is of the same thickness over the whole grain except for the distal apertural zone, in which the sexine elements are very often imperceptible, and a thin foot layer is the only element (Plate IV, 51-52). The tectum is microperforate, with the perforations passing through the entire tectum (Plate IV, 6263). There is considerable variation in tectum thickness. Columellae are present, can be welldeveloped, and are frequently mixed with granules, which are short and irregular in shape. The foot layer varies markedly in thickness, but is usually the thinnest layer in the exine.

The intine is differentiated into three more or less distinctly lamellated layers with different electron densities (Plate IV, 62). It is usually much thicker than the exine. Intine 1 is the outermost layer of the intine, and possesses many vesicular-fibrillar components with tubular extensions. Intine 2 is the middle layer, and contains spherical inclusions. Intine 3 is the innermost and normally the thinnest of the three layers. Its inner margin is in contact with the protoplast.

Specific observations for each genus follow.

2.1.2.1. Manglietia Blume. Distribution: About 30 species in tropical and subtropical Asia, from the eastern Himalayas to South China and Malesia. There are 22 species in China.

Pollen grains of Type 1 (Praglowski, 1974), large, with mean LAs of 57-84 $\mu \mathrm{m}$ across the genus. All species examined have a microperforate ornamentation, which is sparsely distributed in $M$. fordiana and M. megaphylla (Plate II, 30-31). The other species are provided with somewhat ring-like appurtenances on the outer surface of the exine (Plates II, 32; III, 33-34).

Of the five species examined, the tectum is the thickest layer of the exine in three: $M$. megaphylla, M. pachyphylla and M. rufibarbata (Table 2). It is over two times the thickness of the columellar layer in M. rufibarbata (Plate IV, 57). In M. fordiana and M. moto, the columellae are more often slightly thicker than, or as thick as the tectum, varying considerably in thickness and shape within a grain (Plate IV, 55, 58). In other species with very small intraexinous volume it occurs only as irregularly shaped granules (Plate IV, 54, 56-57). The foot layer varies in thickness within a grain. It is thicker than the columellae in M. megaphylla and M. rufibarbata. Its upper surface is uneven, provided with variously shaped depressions of different depths. The lower surface is usually smooth or provided with slight bulges. A distinct, very thin layer with different staining properties and slightly varying in thickness within a grain is visible at the bottom of the foot layer in four of the species examined (M. fordiana, M. megaphylla, $M$. pachyphylla, $M$. rufibarbata). This could indicate the presence of endexine in these species (Plate IV, 54-57). It is distinct from the foot layer in several locations, and is interrupted in others (Plate IV, 55). It is only vaguely distinguishable in $M$. moto (Plate IV, 58).

The intine is usually three times thicker than the exine, but is nearly ten times thicker in $M$. megaphylla. There is relatively little differentiation between intine 2 and 3 (Plate IV, 57-58). 
2.1.2.2. Magnolia L. Distribution: about 90 species are known from temperate and tropical regions of Southeast Asia, southeastern North America and Central America. Thirty-one species occur in China.

Pollen grains usually of Type 1 ( $M$. delavayi, $M$. denudata, $M$. henryi, $M$. paenetalauma), seldom of Type 3 (M. grandiflora); usually large, with mean LAs of 49-91 $\mu \mathrm{m}$ across the genus, but over 100 gm in M. delavayi. The sexine is ornamented with microperforations or may be slightly rugulose (Plate III, 35, 37, 38). The perforations are sparsely distributed in $M$. henryi (Plate III, 36), and provided with somewhat ring-like appurtenances in $M$. grandiflora and M. denudata (Plate III, 38, 39).

The tectum is the thickest in the exine in $M$. grandiflora and $M$. paenetalauma, about as thick as the foot layer in $M$. delavayi, and is one-half the thickness of the columellae in $M$. henryi (Table 2). In M. grandiflora the tectum is much thicker than in other species, and is thicker than the columellae and foot layer.

Irregular columellae are often present, and are usually thicker at the base than the upper end (Plate IV, 59), but are thicker at the upper end in $M$. delayayi (Plate IV, 60). Some granules are attached to the lower surface of the tectum, some to the upper surface of the foot layer (Plate IV, 63). In M. grandiflora, the columellae are very short, and usually spheroidal (Plate IV, 62).

There is a great deal of variation in the thickness and shape of the foot layer. The upper surface is often uneven, and provided with variously shaped depressions of different depths (Plate IV, 61). These depressions nearly reach the level of the endexine in M. denudata (Plate IV, 63). The lower surface of the layer is usually smooth, but can be undulate (Plate IV, 62).

The endexine is distinct, but varies in thickness in different species. It is separated from the foot layer by a white-line-centered lamella, and is interrupted in some areas (Plate IV, 60). The intine is most commonly three times thicker than the exine, but only one and one half times thicker in M. grandiflora.

2.1.2.3. Parakmeria Hu et Cheng. Distribution: five species, distributed in Southeast Asia from southeast Tibet and northeast Burma to Taiwan. All of the species occur in southwest to southeast China. Three of them are androdioecious.

Both of the species observed are dioecio-polygamous, possessing both staminate and bisexual flowers. The pollen grains are large, with mean LAs of $48-85 \mu \mathrm{m}$ across the genus. However, the grains from bisexual flowers of $P$. yunnanensis are much smaller than those from the male flowers (Table 2). Pollen shape from both types of flowers is very similar in both species. It is boat-shaped in P. lotungensis, but spheroidal in P. yunnanensis (Plate II, 23-24). Even with fresh pollen, the grains from the bisexual flowers of both species tend to collapse under SEM, so it is difficult to find an uncollapsed grain.

Pollen grains of Type 1. The sexine is smooth with perforate ornamentation in P. yunnanensis and the male flowers of $P$. lotungensis (Plate III, 40, 42). It is almost without ornamentation in the bisexual flowers of $P$. lotungensis (Plate III, 41). 
The tectum is much thinner than the columellae (Plate V, 64, 65, 67, 68), with a thin zone of weak cohesion between the lower surface of the tectum and the upper ends of the columellae. Granules are particularly abundant on the lower surface of the tectum in P. yunnanensis (Plate V, 64), and are found on the lower surface of the tectum, the upper surface of the foot layer, or in the inter-columellar spaces in P. lotungensis (Plate V, 67, 68).

The foot layer varies in thickness. The upper surface is provided with sparsely spaced bulges, while the lower surface is relatively straight and smooth.

The endexine is distinct and very thin in $P$. yunnanensis, but difficult to discern in $P$. lotungensis.

The intine is often three times thicker than the exine. The inclusions in intine 2 are irregular in shape. Intine 3 is undulate, with discernible lamellation (Plate V, 64, 67).

2.1.2.4. Kmeria Dandy. Distribution: two species are known from South China, Cambodia and adjacent Thailand. Kmeria is the only dioecious genus in the Magnoliaceae.

Pollen grains of Type 5, with a mean LA of $38 \mu \mathrm{m}$ in the genus. The sexine is rugulose with coarse ornamentation, and very minute, granular appurtenances (Plate III, 43). Individual columellae uniformly thick, their width much shorter than their length, directly connected both with the tectum and the foot layer. Sometimes, elongate granules on the tectum combine with bulges from the foot layer to form the columellae (Plate V, 66, 69).

The foot layer is thin, but uneven. Endexine very difficult to discern. Intine less than three times as thick as the exine. Lamellation is discernible in intine 3.

2.1.2.5. Alcimandra Dandy. Distribution: a monotypic genusdistributed in Southeast Asia, from the eastern Himalayas to Vietnam.

Pollen grains of Type 2 , with a mean LA of $35 \mu \mathrm{m}$. The sexine is comparatively smooth, with microperforations (Plate III, 44). The tectum is slightly thicker than the columellae (Plate V, 70). Columellae short, often as thick as wide, occasionally twice as wide.

The foot layer is thin, with a smooth lower surface. The endexine can be quite difficult to discern in some areas. The intine is only one and one half times thicker than the exine.

Spherical inclusions are not present in intine 2. Intine 3 is much thicker than intine 1 . The exine together with the intine is the thinnest in the observed species.

Plate I. LM (1-8) and SEM (9-18) views of the distal face of pollen grains, except 11 and 13 (proximal views) and 14 and 17 (oblique equatorial views). In polar view, the aperture is simple, usually long. (see page 145)

1. Parakmeria lotungensis (male flower).

2. Kmeria septentrionalis. 
3. Michelia balansae.

4. Michelia champaca.

5. Michelia skinneriana.

6. Michelia foveolata.

7. Paramichelia baillonii.

8. Tsoongiodendron odorum.

9. Manglietia fordiana.

10. Manglietia moto.

11. Manglietia megaphylla, showing the pollen grain with a sulcus and a fold of the wall.

12. Manglietia pachyphylla.

13. Manglietia rufibarbata.

14. Magnolia paenetalauma.

15. Parakmeria lotungensis (male flower), showing the close up of end of the aperture.

16. Magnolia delavayi.

17. Parakmeria lotungensis (male flower).

18. Parakmeria lotungensis (bisexual flower). All bars $=5 \mu \mathrm{m}$.

Plate II. SEMs of polar or equatorial views (19-29) and perforate ornamentation of sexine (3032). (see page 146)

19. Magnolia grandiflora pollen grain with a fold in the wall (distal view).

20. Magnolia henryi, equatorial view.

21. Kmeria septentrionalis, distal view.

22. Magnolia denudata, distal view.

23. Parakmeria yunnanensis (bisexual flower), proximal view.

24. Parakmeria yunnanensis (male flower), proximal view.

25. Michelia balansae, equatorial view.

26. Alcimandra cathcartii, equatorial view.

27. Michelia foveolata, equatorial view.

28. Michelia champaca, equatorial view.

29. Paramichelia baillonii, proximal view.

30. Manglietia fordiana.

31. Manglietia megaphylla, with sparsely distributed perforations.

32. Manglietia moto. All bars $=5 \mu \mathrm{m}$.

Plate III. SEMs showing perforate ornamentation of sexine. (see page 147)

33. Manglietia pachyphylla, showing perforations and somewhat ring-like appurtenances.

34. Manglietia rufibarbata.

35. Magnolia delavayi.

36. Magnolia henryi, perforations sparse.

37. Magnolia paenetalauma.

38. Magnolia grandiflora, showing exine perforations, somewhat ring-like appurtenances and a slightly regulate surface.

39. Magnolia denudata.

40. Parakmeria lotungensis (male flower).

41. Parakmeria lotungensis (bisexual flower), with a very smooth exine, almost without ornamentation. 
42. Parakmeria yunnanensis (male flower).

43. Kmeria septentrionalis, showing the coarsely rugulose exine, with very minute, granular appurtenances.

44. Alcimandra cathcartii.

45. Michelia champaca.

46. Michelia balansae.

47. Michelia foveolata, showing rugulose ornamentation consisting of relatively short, wide ridges.

48. Michelia skinneriana, with a coarsely rugulose sexine.

49. Paramichelia baillonii, with microperforations varying noticeably in size.

50. Tsoongiodendron odorum. All bars $=5 \mu \mathrm{m}$. 

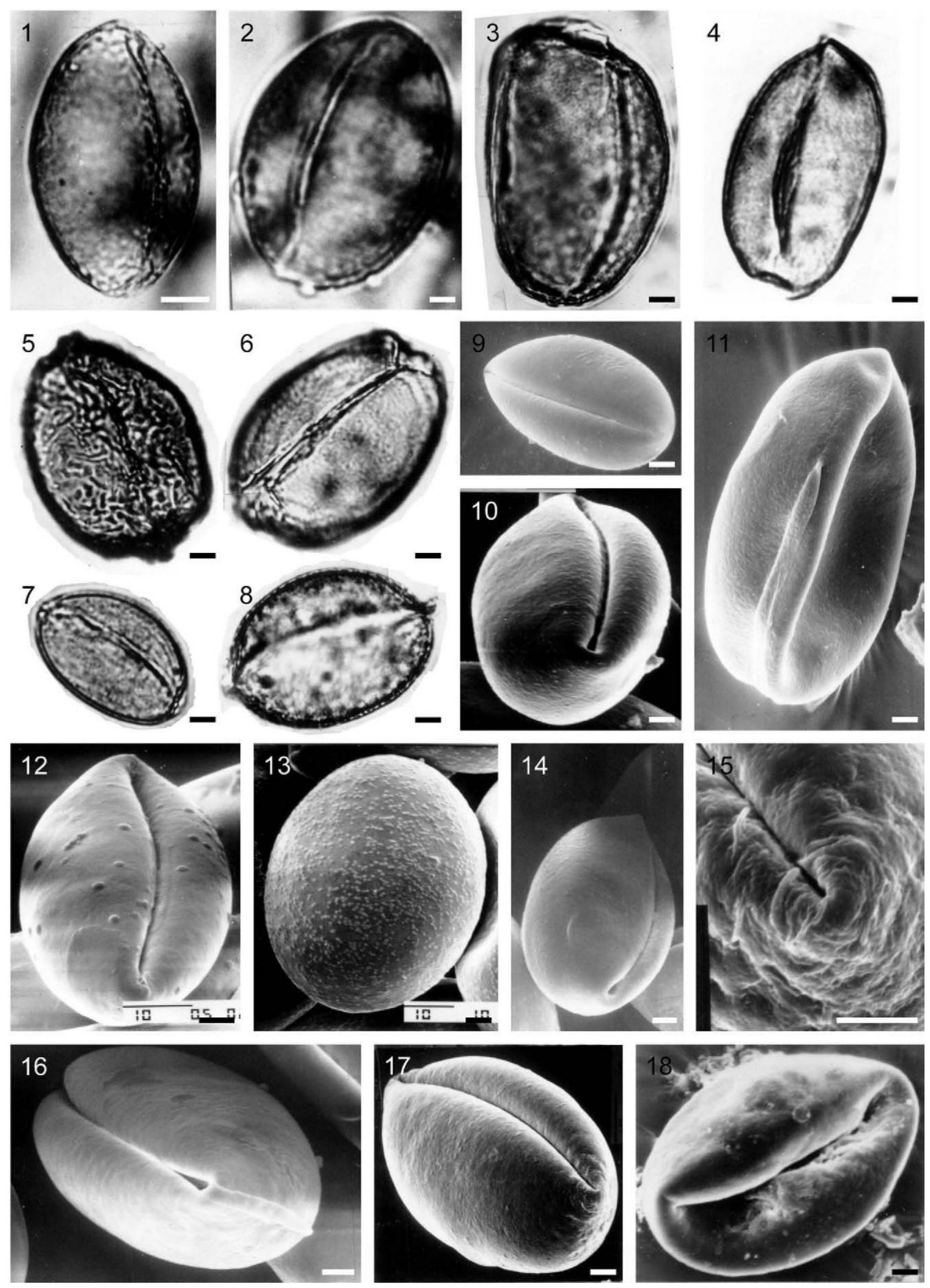
Plate I (see caption on page 144).
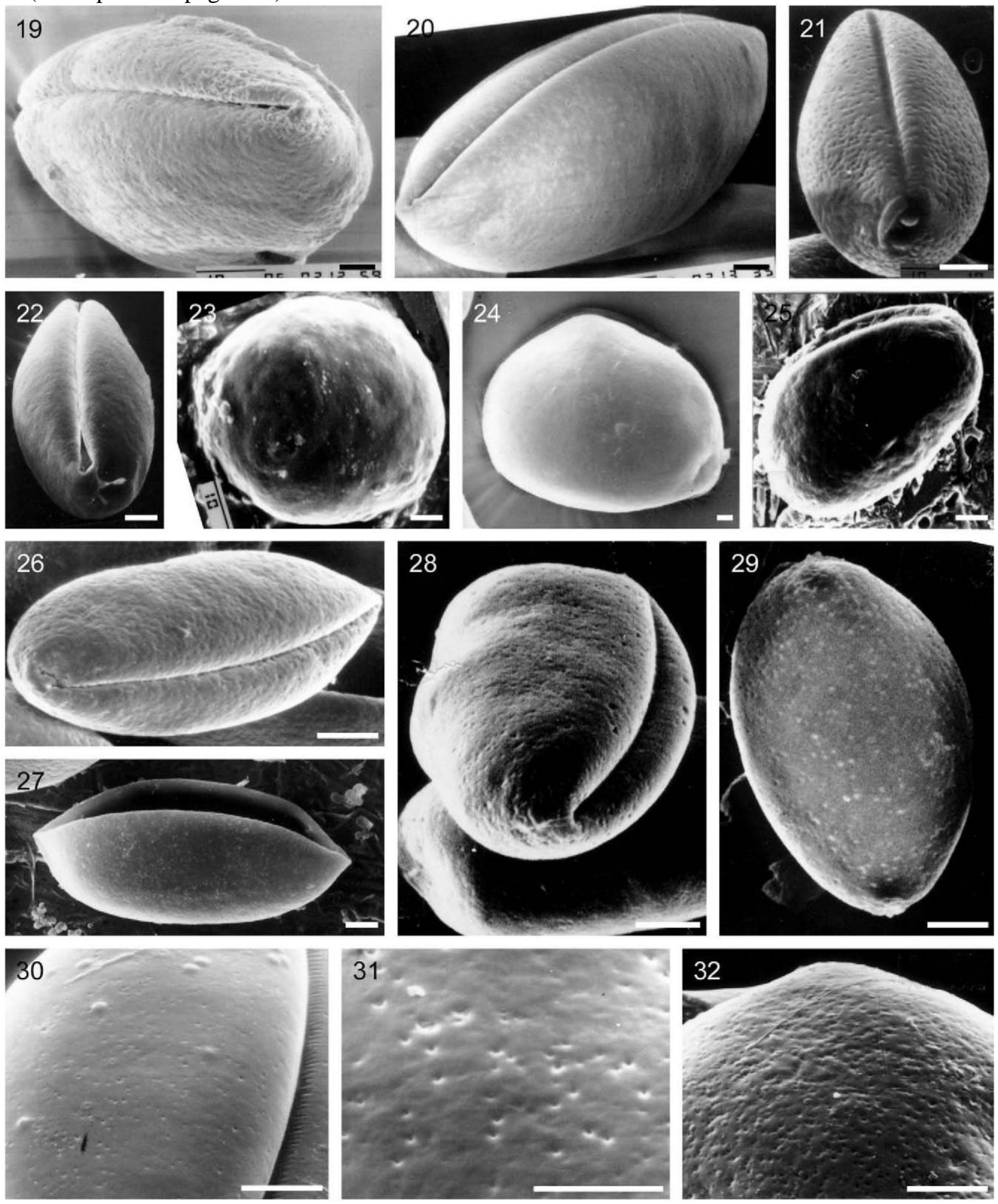

Plate II (see caption on page 144). 
2.1.2.6. Michelia L. Distribution: about 50 species are known from Southeast Asia, India eastwards to China and Japan, and southeastwards into Indonesia. Forty-one species occur in China. Pollen grains of Type 1 or 3. Grains usually large with a mean LA of 47-64 gm across the genus. The sexine is ornamentedmainly with microperforations (Plate III, 45-46), but is rugulose in $M$. skinneriana (Plate III, 48), and consists of relatively short and wide ridges in $M$. foveolata (Plate III, 47).

The tectum is the thickest in the exine in M. foveolata and M. skinneriana, about as thick as the columellae in $M$. champaca, 

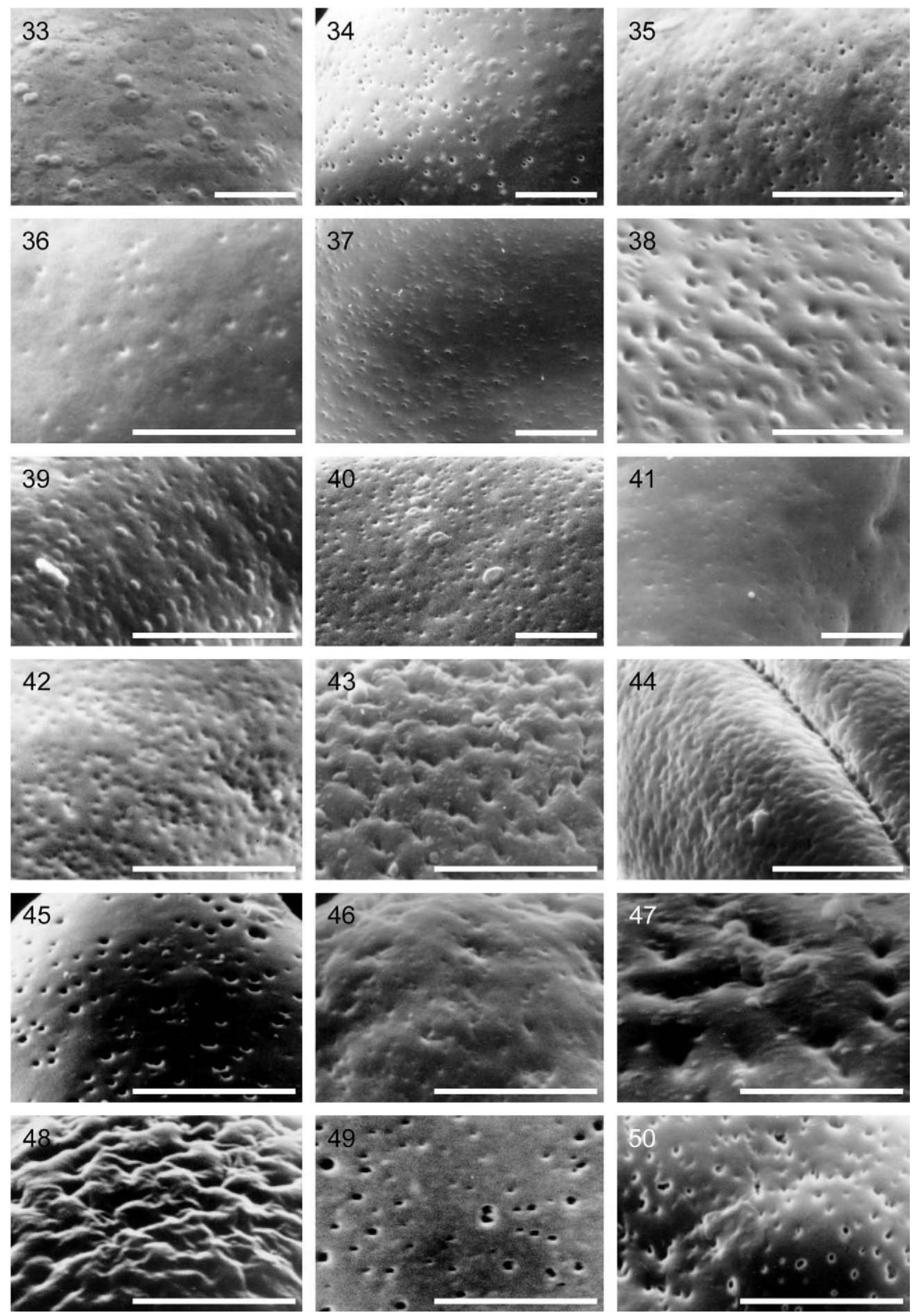
Plate III (see caption on page 144).

and thinner than the columellae in M. balansae (Plate V, 71-74). The columellae are very short (Plate V, 71-72) or lumpy (Plate V, 73-74), and irregular granules are often encountered under the tectum (Plate V, 72-74). The individual columellar elements have a diameter about three times their length (Plate V, 72).

The foot layer varies in thickness, is occasionally much reduced, and is seemingly discontinuous (Plate V, 72). In M. foveolata, the lower surface of the foot layer is usually smooth.

The endexine is distinct in M. foveolata and M. skinneriana, but very difficult to discern in $M$. champaca and $M$. balansea (Plate $\mathrm{V}, 71-74$ ). Intine is usually two to three times thicker than the exine, except in $M$. skinneriana, where it is only one and one half times thicker. The boundary between intine 1 and 2 is comparatively weak in $M$. champaca and $M$. foveolata. In $M$.

foveolata spherical inclusions are not observed in intine 2 , whereas they are present in the other species. Intine 3 is the 

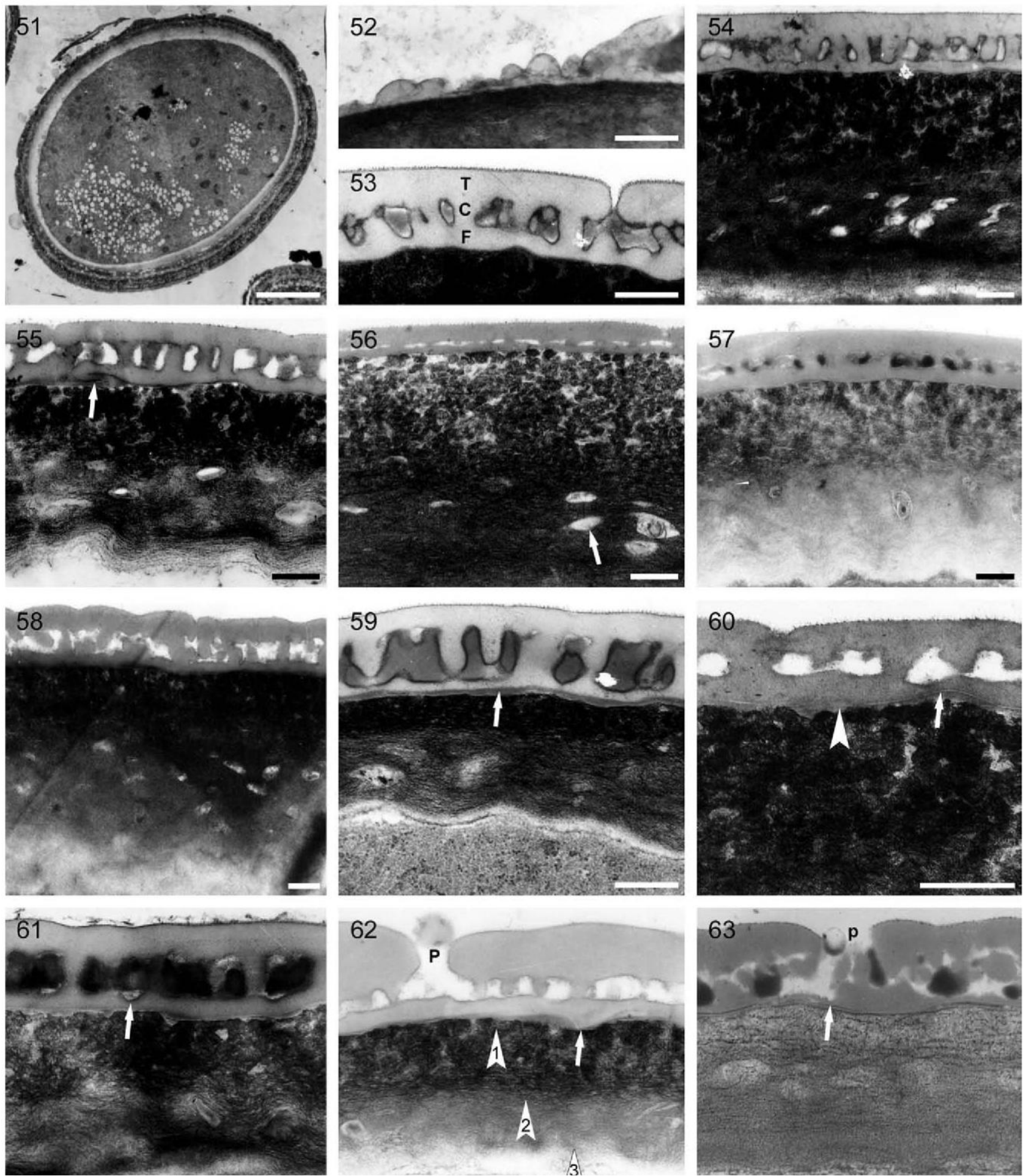

thinnest of the intine layers only in M. balansae. It is thicker, or as thick as intine 1 or 2 in other species.

2.1.2.7. Paramichelia Hu. Distribution: three species are known in Southeast Asia, from Assam to Southwest China and southwards to Sumatra. Only one species occurs in China. 
Pollen grains of Type 2, with a mean LA of $23 \mathrm{gm}$ in the genus, giving the genus the smallest pollen of all those investigated. The sexine is smooth with varying size micro- perforations (Plate $\mathrm{V}, 49$ ). Tectal perforations about $0.35 \mathrm{gm}$ in diameter, the largest diameter in the materials observed. Tectum thinner than the columellae, the inner surface generally encrusted with irregular granules (Plate V, 75). Columellae somewhat irregular. Foot layer varying in thickness. The endexine is quite difficult to discern. Intine is one and one half times thicker than the exine. Intine 2 is without inclusions.

2.1.2.8. Tsoongiodendron Chun. Distribution: a monotypic genus, endemic to Southeast China. Pollen grains of Type 2, with a mean LA of $40 \mathrm{gm}$. Sexine smooth, ornamented with microperforations (Plate III, 50). Tectum is slightly thicker than the columellae, which are often slightly oblique and somewhat regular. Foot layer relatively smooth on the lower surface, with some bulges and sparse depressions on the upper surface. The endexine is quite difficult to discern. The intine is more than twice as thick as the exine (Plate V, 76).

\section{DISCUSSION}

\subsection{Pollen shape and size}

Most previous descriptions of Magnoliaceae pollen are based on the study of herbarium or FAA fixed materials. Observation of fresh pollen agrees with these descriptions in showing that the grains are boat-shaped, with rounded or occasionally somewhat pointed ends. The grains are frequently biconvex in lateral view. In one species (Parakmeria yunnanensis) the pollen was field collected and fixed in FAA. This treatment caused the grains to appear remarkably misshapen when viewed with SEM. Very few uncollapsed grains were found. Fresh observations of other species show that the pollen grains are comparatively large, with a relatively thin exine (ca. $1 \mathrm{gm}$ thick). They tend to collapse when observed dry or after acetolysis treatment.

In the materials investigated, the mean LA of the grains varies from 23-91 gm across these species. The species Magnolia paenetalauma, Parakmeria yunnanensis (bisexual flower), Kmeria septentrionalis, Alcimandra cathcartii, Michelia skinneriana, Paramichelia baillonii and Tsoongiodendron odorum have pollen grains in which the mean LA is between 23 and $49 \mathrm{gm}$. According to the size classification of Doyle (2005), they belong to the medium-sized category, which ranges from 20-50 gm. In contrast, large pollen grains are found in all species of Manglietia and most species of Magnolia, Parakmeria, and Michelia. In these species, pollen size means range from 50-91 gm. Walker (1976b) suggested that primitive angiosperms had large pollen in the size range 50-99 gm. However, this supposition has not been supported by recent molecular phylogenetic analyses (Doyle, 2005). All of the basal groups in these analyses, except Nymphaeales, have medium-sized pollen, which can therefore be inferred to be ancestral (Doyle, 2005).

\subsection{Tectal ornamentation and aperture}

Microperforate ornamentation of the sexine is more frequent than rugulose ornamentation. In both the genus Magnolia and Michelia, one or two species have slightly rugulose or rugulose ornamentation (Table 1). The genus Kmeria is coarsely rugulose, and the genus Liriodendron has a verrucate ornamentation (Praglowski, 1974; Wei and Wu, 1993). 
In species of Manglietia pachyphylla, Magnolia grandiflora and Kmeria septentrionalis, some ring-like appurtenances were observed. Since no counterparts of these structures appearing in the electron micrographs, they can not be part of the pollen wall. It is possible that they are droplets of pollenkitt emerging from the microperforations.

Praglowski (1974) reported that the pollen of Alimandra cathcartii and Magnolia kobus has a triradiate aperture. However, all species investigated in this study, including A. cathcartii, are monosuclate. This finding is in agreement with the detailed investigations of Canright (1953) and Agababian (1972), who reported an unbranched aperture. Perhaps Praglowski (1974) mistook the folds that sometimes occur in the pollen wall for a triradiate aperture.

Plate IV. Ultrastructure of the pollen wall. All TEM.

51. Section through an entire pollen grain of Paramichelia baillonii.

52. Parakmeria lotungensis (male flower), showing a thin foot layer as the only exine element on the distal aperture zone.

53. Manglietia pachyphylla, detail of 54.

54. Manglietia pachyphylla, with irregularly shaped granules of columellae included in a very small intraexinous volume.

55. Manglietia fordiana, showing the endexine split from the foot layer in some areas and interrupted in others (arrow).

56. Manglietia megaphylla, with an intine nearly ten times thicker than the exine. The arrow points to spherical inclusions in the intine 2.

57. Manglietia rufibarbata, showing a tectum as the thickest layer of the exine, over two times the thickness of the columellae.

58. Manglietia moto, showing columellae slightly longer than the thickness of the tectum, and a vaguely distinguishable endexine.

59. Magnolia henryi, with columellae longer than the thickness of the tectum, endexine distinct (arrow).

60. Magnolia delavayi, showing columellae thicker at the upper end and granules present beneath the lower surface of the tectum. The endexine is separated from the foot layer by a white-line-centered lamella (arrow), and is interrupted in some areas (arrow head).

61. Magnolia paenetalauma, showing depressions on the upper surface of the foot layer (arrow).

62. Magnolia grandiflora, showing the three layers of the intine (numbered arrowheads). Bulges are present on the lower surface of the foot layer (arrow).

63. Magnolia denudata, with abundant granules attached to the upper surface of the foot layer, which has relatively deep depressions nearly reaching the level of the endexine (arrow). $\mathrm{C}=$ columellae, $\mathrm{F}=$ foot layer, $\mathrm{T}=$ tectum, $\mathrm{P}=$ perforation. All bars $=0.5 \mathrm{gm}$, except in $51=5 \mathrm{gm}$.

\subsection{Exine structure}

Walker and Skvarla (1975) suggested that the genus Aromadendron has the most primitive exine structure in the family, with intraexinous cavities so small that the grains approach an atectateamorphous condition. In the present study, the exine of Manglietia macrophylla and $M$. rufibarbata has a very thin columellar layer (less then $0.1 \mu \mathrm{m}$ ), about one-fifth of the whole exine thickness, with very small intraexinous spaces. This is very similar to the condition 
reported in Aromadendron. As the intraexinous space becomes larger, the columellar layer reaches ca. one half or more of the thickness of the exine (Manglietia moto, Magnolia
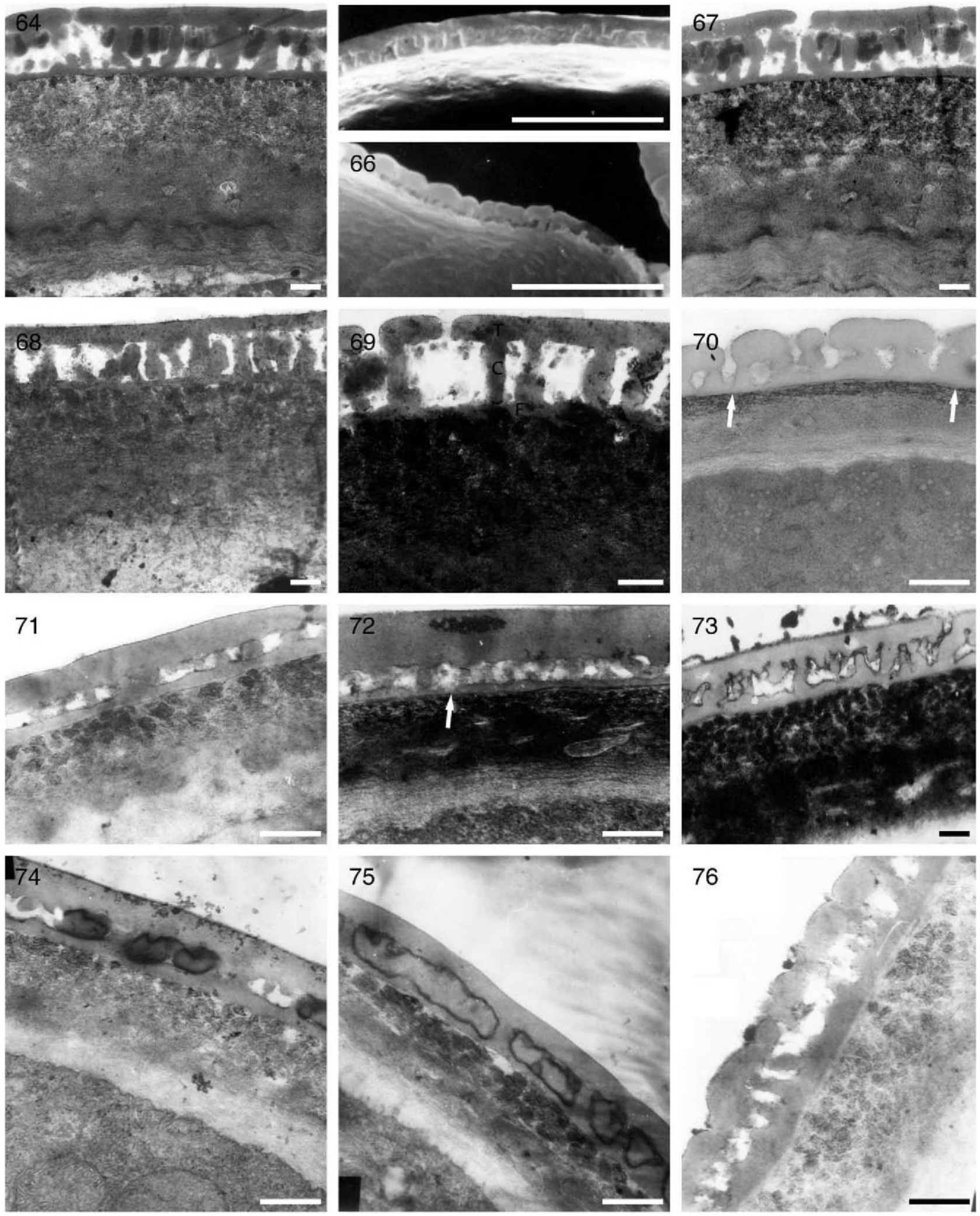
denudata, Magnolia henryi, Parakmeria lotungensis, Parakmeria yunnanensis, Kmeria septentrionalis, Michelia balansae and Paramichelia bailonii). A transformation series of exine structure is found from irregular granules mixed with oblique columellae, to columellae of more normal rod-like elements. Very few species (e.g., Kmeria septentrionalis, Liriodendron tulipifera) possess regular rod-like columellae, that are much taller than the thickness of the tectum (Praglowski, 1974; Wei and Wu, 1993).

Doyle and Endress (2000) recognized three character states in the infratectal structure: granular, intermediate and columellar. Among these, the intermediate state (including columellae apparently composed of fused granules, columellae mixed with granules, and radially elongated, ellipsoidal elements) was considered ancestral. As part of his latest phylogenetic analysis of basal angiosperms, Doyle (2005) revised this character to partition the data differently and reconstructed the columellar structure as ancestral (Doyle, 2005).

The present and previous studies (Praglowski, 1974; Walker, 1976a) indicate that most Magnoliaceae have intermediate columellar structure, as defined by Doyle (2005). Kmeria septentrionalis is one of the few exceptions to this rule, with regular columellae.

\subsection{Endexine}

The endexine is the inner part of the exine, is located above the foot layer and has a different electron density than the foot layer (Punt et al., 2007).

Praglowski (1974) observed and illustrated the endexine in 16 species from 10 genera of the Magnoliaceae. According to him, the endexine is indistinct or difficult to discern in Magnolia liliiflora, Elmerrillia mollis, Michelia floribunda and Paramichelia baillonii. In the present investigation, the endexine is distinct in 14 species, representing all species from Manglietia and Magnolia, and half of the species from Parakmeria and Michelia. It is lacking in some areas of the grains of Alcimandra. In the genera Kmeria, Paramichelia and Tsoongiodendron the endexine is quite difficult to discern.

Walker (1976a) speculated that the endexine in the Magnoliaceae does not have the same appearance as in higher dicotyledons. Both Doyle et al. (1975) and Walker (1976a) suggested that the endexine is absent from primitive species of angiosperms and reappears in advanced ones. Walker and Walker (1984) and Brenner (1996) both agreed that, primitively, angiosperm pollen does not have an endexine. Due to the different interpretation of this term by different authors, it is difficult to compare our results with previous work. However, according to Punt's definition (Punt et al., 2007), the present study and El-Ghazaly's (2001) observations indicate that an endexine, which is easily overlooked in some Magnoliaceous species, is indeed present in this primitive family. The interpretation of the layer in question as endexine is supported by Gabarayeva's (1991b) developmental definition of endexine based on its origin from lamellae deposited below the foot layer. By this definition, the foliations in the Magnoliaceae are clearly endexine. The latest phylogenetic analyses also conclude that a thin endexine appears to be the ancestral state in the angiosperms (Doyle, 2005; Sampson, 2000).

\subsection{Intine}


The present study supports Praglowski's (1974) concept of the intine as differentiated into three, more or less distinctly lamellated layers with different electron densities. Intine 1 is the outermost layer and appears as an electron dense layer consisting of membranous radial units, intermingled with granular material. This layer was identified as part of the endexine or the intine by Gabarayeva (1987a,b). Gabarayeva and Hemsley (2006) considered this layer as belonging to the endexine. El-Ghazaly and Huysmans (2001) suggested that it was neither endexine nor intine based on the pollen wall development of Magnolia grandiflora. They described the ultrastructural morphology of this layer, but without creating a new term.

\subsection{Pollen size and chromosome number}

Due to the wide variation of pollen size and chromosome number in this family, an attempt was made to determine if there

Plate V. Structure of the pollen wall. All TEM, except 65, 66 SEM.

64. Parakmeria yunnanensis (male flower), with abundant granules attached to either the lower surface of the tectum, or the upper surface of the foot layer. The endexine is distinct and very thin.

65. Parakmeria lotungensis (male flower) freeze-fracture showing pollen wall structure.

66. Kmeria septentrionalis freeze-fracture showing pollen wall structure.

67. Parakmeria lotungensis (bisexual flower), showing the undulate intine 3 with discernible lamellation.

68. Parakmeria lotungensis (male flower), with an endexine that is rather difficult to discern.

69. Kmeria septentrionalis with well developed individual columellae directly connected both to the tectum and the foot layer. The endexine is very difficult to discern.

70. Alcimandra cathcartii, showing short columellae. The lower surface of the foot layer is rather smooth. The endexine can not be seen in some areas (arrows).

71. Micheliafoveolata, with very short columellae. The lower surface of the foot layer is usually smooth. Spherical inclusions seem to be absent from intine 2.

72. Michelia skinneriana with a discontinuous foot layer in some areas (arrow); endexine distinct.

73. Michelia balansae, with irregular granules present under the tectum. The endexine is very difficult to discern.

74. Michelia champaca, with an endexine that is difficult to discern, and the demarcation between intine 1 and 2 comparatively indistinct.

75. Paramichelia baillonii with an endexine that is difficult to discern.

76. Tsoongiodendron odorum, showing columellae are sometimes regular but often oblique. The foot layer has a relatively smooth lower surface, with bulges and depressions in its upper surface. The endexine is difficult to discern. $\mathrm{C}=$ columellae, $\mathrm{F}=$ foot layer, $\mathrm{T}=$ tectum. All bars $=0.5 \mu \mathrm{m}$, except in $65,66=5 \mu \mathrm{m}$.

is a correlation between these two factors. A commonly held concept suggests that species (within a genus) with larger chromosome number will have, as a rule, larger pollen grains (Erdtman, 1952). In the genus Magnolia, the only known tetraploid (M. denudata) and hexaploid (M. grandiflora) have pollen not significantly larger than the diploid species, thus undermining the hypothesis. 


\section{CONCLUSION}

The shape of the pollen grains, the type of aperture and the intine ultrastructure all show a remarkable uniformity in the genera investigated in this study, thus indicating that the Magnoliaceae as circumscribed by Dandy (1927) represent a homogeneous group from a pollen morphological point of view. Nevertheless there is variation in pollen size, ornamentation and the ultrastructure of the exine.

The ancestral angiosperms have been inferred to have globose monosulcate pollen with columellae and a thin endexine, rather than boat-shaped monosulcate pollen with a granular infratectum and no endexine (Doyle, 2005). Based on this understanding, the pollen morphology and ultrastructure of most Magnoliaceae is intermediate in structure. The gains are monosulcate and have an endexine. The endexine is distinct, and stains differently than the foot layer in 14 of the 20 species examined. However, the grains are boat-shaped, not globose (only Parakmeria yunnanensis is globose). Most species have columellae mixed with granules. Very few have typical columellae (e.g. Kmeria septentrionalis, Liriodendron tulipifera). Magnoliaceae pollen is an example of an early trend of specialization in pollen structure. The results presented here support the view that the Magnoliaceae are not one of the earliest lines in angiosperms phylogeny.

\section{Acknowledgements}

The authors are grateful to Ms. Xiao-Ying Hu and Ms. Xing- Lan Xu for technical assistance, and to Ms. Ying-Zhi Liu for collecting some of the samples. The research was financially supported by grants from the National Science Foundation of China (30770140, 30370108), the Guangdong Provincial Natural Science Foundation (5006764) and the SRF for ROCS, SEM.

\section{REFERENCES}

- Agababian, V.S., 1972. Pollen morphology of the family Magnoliaceae. Grana 12,

- $166-176$.

- Angiosperm Phylogeny Group, 2003. An update of the Angiosperm Phylogeny Group classification for the orders and families of flowering plants: APGII. Bot. J. Linn. Soc. 141, 399-436.

- Azuma, H., Garcia-Franco, J.G., Rico-Gray, V., Thien, L.B., 2001. Molecular phylogeny of the Magnoliaceae: the biogeography of tropical and temperate disjunctions. Am. J. Bot. 88, 2275-2285.

- Brenner, G.J.,1996. Evidence for the earliest stage of angiosperm pollen evolution: a paleoequatorial section from Israel. In: Taylor, D.W., Hickey, L.J. (Eds.), Flowering Plant Origin, Evolution and Phylogeny. Chapman and Hall, New York, pp. 91-115.

- Canright, J.E., 1953. The comparative morphology and relationships of the Magnoliaceae II, significance of the pollen. Phytomorphology 3, 355-365. Cheng, B.L., Nooteboom, H.P., 1993. Notes on Magnoliaceae III, the Magnoliaceae of China. Ann. Mo. Bot. Gard. 80, 999-1104.

- Doyle, J.A., 2005. Early evolution of angiosperm pollen as inferred from molecular and morphological phylogenetic analyses. Grana 44, 227-251.

- Doyle, J.A., Endress, P.K., 2000. Morphological phylogenetic analysis of basal angiosperms: comparison and combination with molecular data. Int. J. Plant Sci. 161, S121-S153 (Suppl.). 
- Doyle, J.A., Van Campo, M., Lugardon, B., 1975. Observations on exine structure ofEucommiidites and Lower Cretaceous angiosperm pollen. Pollen Spores 17, 429-484.

- Dandy, J.E., 1927. The genera of Magnoliaceae. Kew Bull. 1927, 257-263.

- Dandy, J.E., 1964. Magnoliaceae. In: Hutchinson, J. (Ed.), The Genera of Flowering Plants, vol. I. Oxford University Press, Oxford, pp. 50-57.

- Erdtman, G.,1952. Pollen morphology and plant taxonomy. Angiosperms. Almqvist and Wiksell, Stockholm.

- Erdtman, G., 1960. The acetolysis method, a revised description. Sven. Bot. Tidskr. 54, 561-564.

- Erdtman, G., 1969. Handbook of Palynology - An Introduction to the Study of Pollen Grains and Spores. Munksgaard, Copenhagen.

- El-Ghazaly, G., 2001. Development ofMagnolia grandiflora pollen wall. Jpn. J. Histo. Bot. 9, 61-78.

- El-Ghazaly, G., Huysmans, S., 2001. Re-evaluation of a neglected layer in pollen wall development with comments on its evolution. Grana 40, 3-16.

- Figlar, K.B., Nooteboom, H.P., 2004. Notes on Magnoliaceae IV. Blumea 49, $87-100$.

- Gabarayeva, N.I., 1986. The development of the exine in Michelia fuscata (Magnoliaceae) in connection with the changes in cytoplamic organelles of microspores and tapetum. Botanicheskiy Zhurnal (Leningrad) 71, 311-322 (in Russian, with English summary).

- Gabarayeva, N.I., 1987a. Ultrastructure and development of endexine lamellae in Manglietia tenuipes (Magnoliaceae) in connection with the question of endexine existence in primitive angiosperms. Botanicheskiy Zhurnal (Leningrad) 72, 1310-1317 (in Russian, with English summary).

- Gabarayeva, N.I., 1987b. Ultrastructure and development of pollen grain wall in Manglietia tenuipes (Magnoliaceae): the formation of intine in connection with the activity of cytoplasmic organelles. Botanicheskiy Zhurnal (Leningrad) 72, 1470-1477 (in Russian, with English summary).

- Gabarayeva, N.I.,1991 a. Ultrastructure and development of exine and orbicules in Magnolia delavayi (Mangoliaceae) during tetrad and at the beginning of posttetrad period. Botanicheskiy Zhurnal (Leningrad) 76,10-19 (in Russian, with English summary).

- Gabarayeva, N.I., 1991b. Patterns of development in primitive angiosperm pollen. In: Blackmore, S., Barnes, S.H. (Eds.), Pollen and Spores. Clarendon Press, Oxford, pp. 257-268.

- Gabarayeva, N.I., 1996. Sporoderm development in Liriodendron chinense (Magnoliaceae): a probable role ofthe endoplasmic reticulum. Nord. J. Bot. 16, 307-323.

- Gabarayeva, N.I., Hemsley, A.R., 2006. The role of self-assembly in the development of pollen wall structure. Rev. Palaeobot. Palynol. 138, 121-139.

- Kim, S., Park, C.W., Kim, Y.D., Suh, Y., 2001. Phylogenetic relationships in family Magnoliaceae inferred from ndhF sequences. Am. J. Bot. 88, 717-728.

- Law, Y.W.,1984. A preliminary study on the taxonomy ofthe family Magnoliaceae. Acta Phytotaxon. Sin. 22, 80-109. 
- $\quad$ Li, X.L., Song, W.Q., An, Z.P., Chen, R.Y., 1998a. The karyotype analysis of Michelia (Magnoliaceae) in China. Acta Phytotaxon. Sin. 36, 145-149.

- Li, X.L., Song, W.Q., An, Z.P., Chen, R.Y., 1998b. Karyotype analysis of some species of Magnolia in China. Acta Bot. Yunnan. 20, 204-206.

- Long, H., 1982. Magnoliaceae. In: Institute of Botany, South China Institute of Botany, Academia Sinica (Eds.), Angiosperm Pollen Flora of Tropic and Subtropic China. Science Press, Beijing, pp. 199-202.

- Meng, A.P., Wang, H.C., Li, J.Q., Sima, Y.K., 2006. A karyomorphological study of 40 species in 11 genera ofthe Magnoliaceae from China. Acta Phytotaxon. Sin. 44, 47-63.

- Nooteboom, H.P., 1985. Notes on Magnoliaceae. Blumea 31, 65-121.

- Nooteboom, H.P., 2000. Different looks at the classification of the Magnoliaceae. In: Liu, Y.H., Fan, H.M., Chen, Z.Y., Wu, Q.G., Zeng, Q.W. (Eds.), Proceedings of the International Symposium of the Family Magnoliaceae. Science Press, Beijing, pp. 26-37.

- Praglowski, J., 1974. Magnoliaceae Juss. World Pollen Spore Flora 3, 1-45. Punt, W., Hoen, P.P., Blackmore, S., Nilsson, S., L e Thomas, A., 2007. Glossary of pollen and spore terminology. Rev. Palaeobot. Palynol. 143, 1-81.

- Sampson, F.B., 2000. Pollen diversity in some modern magnoliids. Int. J. Plant Sci. 161, S193-S210 (Suppl.).

- Sauquet, H., Doyle, J.A., Scharaschkin, T., Borsch, T., Hilu, K.W., Chatrou, L.W., L e Thomas, A., 2003. Phylogenetic analysis ofMagnoliales and Myristicaceae based on multiple data sets: implications for character evolution. Bot. J. Linn. Soc. 142, 125-186.

- Walker, J.W., 1976a. Evolutionary significance of the exine in the pollen of primitive angiosperms. In: Ferguson, I.K., Muller, J. (Eds.), The Evolutionary Significance of the Exine. Academic Press, London, pp. 251-308. Walker, J.W., 1976b. Comparative pollen morphology and phylogeny of the ranalean complex. In: Beck, C.B. (Ed.), Origin and Early Evolution of Angiosperms. Columbia University Press, New York, pp. 241-299.

- Walker, J.W., Skvarla, J.J.,1975. Primitively columellalesspollen: anew concept in the evolutionary morphology of angiosperms. Science 187, 445-447.

- Walker, J.W., Walker, A.G., 1984. Ultrastructure of Lower Cretaceous angiosperm pollen and the origin and early evolution of flowering plants. Ann. Mo. Bot. Gard. 71, 464-521.

- Wei, Z.X., Wu, Z.Y., 1993. Pollen ultrastructure of Liriodendron and its systematic significance. Acta Bot. Yunnan. 15, 163-166. 